Article

\title{
Onion Peel Powder as an Antioxidant-Rich Material for Sausages Prepared from Mechanically Separated Fish Meat
}

\author{
Jan Bedrníček ${ }^{1, *(1)}$, Jaromír Kadlec ${ }^{1}$, Ivana Laknerová ${ }^{2}{ }^{(0}$, Jan Mráz ${ }^{3}{ }^{(0)}$, Eva Samková ${ }^{1}{ }^{1}$, \\ Eva Petrášková ${ }^{4}$, Lucie Hasoňová ${ }^{1}$, František Vácha ${ }^{1}{ }^{(D}$, Vladimír Kron ${ }^{1}$ and Pavel Smetana ${ }^{1}$ \\ 1 Department of Food Biotechnologies and Agricultural Products' Quality, Faculty of Agriculture, \\ University of South Bohemia in České Budějovice, Studentská 1668, 37005 České Budějovice, \\ Czech Republic; kadlec@zf.jcu.cz (J.K.); samkova@zf.jcu.cz (E.S.); hasonova@zf.jcu.cz (L.H.); \\ fvacha@zf.jcu.cz (F.V.); vladimir.kron@trouwnutrition.com (V.K.); smetana@zf.jcu.cz (P.S.) \\ 2 Food Research Institute Prague, Radiová 1285/7, 10200 Praha 10, Hostivař, Czech Republic; \\ ivana.laknerova@vupp.cz \\ 3 South Bohemian Research Center of Aquaculture and Biodiversity of Hydrocenoses, Institute of Aquaculture \\ and Protection of Waters, Faculty of Fisheries and Protection of Waters, University of South Bohemia in \\ České Budějovice, Na Sádkách 1780, 37005 České Budějovice, Czech Republic; jmraz@frov.jcu.cz \\ 4 Department of Animal Husbandry Sciences, Faculty of Agriculture, University of South Bohemia in \\ České Budějovice, Studentská 1668, 37005 České Budějovice, Czech Republic; epetraskova@zf.jcu.cz \\ * Correspondence: bedrnj00@zf.jcu.cz; Tel.: +420-721-657-114
}

Received: 21 September 2020; Accepted: 10 October 2020; Published: 11 October 2020

\begin{abstract}
Mechanically separated fish meat (MSFM) can be used for the manufacturing of ready-to-eat products, such as sausages; however, it is highly perishable. Several plant by-products, including onion peel, which is rich in polyphenol antioxidants, can be added to food to extend shelf life. This study investigated the effects of the addition of onion peel powder (OPP) to sausage made from MSFM. Sausages were divided into four groups with different amounts of added OPP: $0 \%$ (control), $1 \%, 2 \%$, and $3 \%$. Cooked sausages were stored for 28 days at $5^{\circ} \mathrm{C}$. Samples were analyzed for thiobarbituric acid reactive substances, antioxidant activity, total polyphenol content, $\mathrm{pH}$, and organoleptic properties. The addition of OPP significantly increased antioxidant activity and total polyphenol content and decreased $\mathrm{pH}$, indicating acidic nature of OPP. Polyphenols from OPP effectively suppressed lipid oxidation. A 1-2\% addition of OPP enhanced sensory properties. After the 28-day storage, the control samples received the lowest sensory score, due to the presence of a strong fishy odor, which was not present in samples with OPP. HPLC-MS/MS analysis revealed that quercetin is the most dominant compound in OPP. Overall, the results indicate that the addition of OPP in amounts of $1-2 \%$ can extend shelf life, without the deterioration of sensory properties.
\end{abstract}

Keywords: mechanically deboned fish meat; onion peel powder; shelf life; fish sausage

\section{Introduction}

Fish meat is a nutritionally valuable part of the human diet, and consuming it two times a week is recommended, mostly due to the content of long-chain polyunsaturated n-3 fatty acids with a positive impact on human health [1].

In 2018, about $88 \%$ (of total 179 million tons) of fish production was utilized for direct human consumption, primarily in live, fresh, or chilled form; however, the fish industry often extracts only fillets. The remaining $12 \%$ was used for non-food purposes, such as fish meal or fish oil [2,3].

Fish processing is closely related to the production of a wide range of waste or by-products. The edible proportion of fish represents approximately $45 \%$ of total fish weight; therefore, $55 \%$ of the fish 
can be considered as a waste from processing, including heads, guts, bones, skin, fins, frame, and meat adhered to bones and skin [4]. On the other hand, mechanically separated fish meat (the meat originally adhered to heads, bones, and skin) from commercial fish processing and from fish that is not acceptable, such as fillets and whole fish with non-commercial size, is considered as fish waste, which can be consumed by humans, and, therefore, could be used for the manufacturing of ready-to-eat products [5].

According to Vanhonacker et al. [6], some people may have an aversion to fish consumption. The reason for this is the perceived difficulty in buying, preparing, and cooking; the belief that it is expensive; or due to the unpleasant properties of some varieties of fish, such as the presence of bones and the smell [7]. A ready-to-eat product such as fish sausage could overcome the abovementioned barriers for consumers, and thus might be more easily acceptable.

Unfortunately, fish meat has very short shelf life. A far worse situation is in the case of the utilization of product specific waste. The reasons are high water content, suitable environment for microorganisms, high level of enzymatic activity, and fast oxidation of lipids. The changes start immediately after a fish's death [8,9].

The incorporation of antioxidants is considered as an effective method to inhibit or delay the lipid oxidation that may result in negative sensory and nutritional changes of meat products, thereby extending the shelf life of products. Despite synthetic antioxidants having been used in recent years, the demand for natural antioxidants has been increasing mainly because of the potentially adverse effects of synthetic antioxidants on human health. Thus, it is becoming increasingly trendy to investigate the effects of natural antioxidants from plant sources (e.g., cereals, fruits, and vegetables) as food products additives [10-13].

These plant sources could be, for example, vegetable-processing by-products, such as onion peel. Onion (Allium cepa L.) is the second most cultivated vegetable in the world, and thousands of tons of waste, generated during its processing, are produced annually just in the European Union [14]. It has been reported that onion peel contains high amounts of dietary fiber, as well as polyphenolic antioxidants, mainly quercetin and its derivatives, which belong to a group of flavonoids $[15,16]$.

Onion flavonoids are well-known for their health benefits, such as antioxidant, anti-inflammatory, antimicrobial, and anticancer effects. In addition, flavonoids play an important role in prevention against oxidative stress, which is a risk factor for development of cardiovascular and neurological diseases [17].

Onion peel or onion-peel extracts (either water or ethanol) have increasingly attracted more attention during the last few years as a functional food ingredient which has been incorporated, for example, into wheat bread [18], gluten-free bread [19], and meat patties [20-22], to promote health benefits or prolong product shelf life.

Therefore, the aim of this study was to investigate the effects of the incorporation of onion peel powder (OPP) into a sausage prepared from mechanically separated fish meat on selected chemical, technological, and sensory properties.

\section{Materials and Methods}

\subsection{Raw Material}

Dry and soil-free middle layers of onion peels of the yellow variety Hybelle were donated by a Czech grower of onions (VITAL Czech s.r.o., Všestary, Czech Republic). Onion peels (water content approximately $12 \%$ ) were ground into a fine onion peel powder (OPP) with particles equal to or smaller than $250 \mu \mathrm{m}$ and stored at room temperature in the dark until further use. The OPP was then subjected to an analysis of its basic chemical composition, antioxidant activity, polyphenols, and water-holding capacity determination.

Mechanically separated fish meat of the common carp (Cyprinus carpio L.) was bought frozen, at $-18{ }^{\circ} \mathrm{C}$ (freshly produced, only several days old), from a local fish producer (FISH MARKET a.s., České Budějovice, Czech Republic). The separated meat came from fish skeletons (including spine and ribs without head) with adhered meat that remained after filleting. The eggs and pork belly were 
bought fresh at local markets 1 day prior to the experiment and stored overnight at $5{ }^{\circ} \mathrm{C}$. Several hours before sausage preparation, pork fatback was put into a freezer $\left(-18^{\circ} \mathrm{C}\right)$ to be frozen and easily chopped in a bowl cutter. The spices used for sausage production were purchased from GOLDEN WAY spol. s r. o., Plzeň, Czech Republic. Natural pork casing (diameter 34-36 mm) was purchased from HEROLD ŘEZNICKÉ POŤ̌EBY s.r.o., Rakovník, Czech Republic.

\subsection{Preparation of Fish Sausages}

Four treatment groups (control and three experimental) were selected to determine the effect of the addition of OPP on the physicochemical and sensory properties of fish-pork sausages. The control group of sausages was prepared according to this recipe (all percentages in control mixture are $w / w$ ): mechanically separated fish meat $49.2 \%$, pork belly $32.8 \%$, garlic $0.4 \%$, salt $1.6 \%$, black pepper $0.2 \%$, caraway seeds $0.1 \%$, marjoram $0.03 \%$, chili pepper $0.2 \%$, paprika $0.5 \%$, egg $2.7 \%$, and ice $12.3 \%$. In the experimental groups, the control mixture was replaced by $1 \%, 2 \%$, and $3 \%(w / w)$ of OPP (Supplementary Materials Table S1).

The fish and pork meat were chopped into small pieces and weighed separately, according to the recipe. The ingredients were then mixed in a bowl cutter (MTK 661, MADO GmbH, Dornhan, Germany) in the following order: Firstly, pork belly and mechanically separated fish meat were slowly minced with ice. Secondly, salt and spices were added, and, finally, OPP was added at the end of mixing. The total time of mixing of the ingredients was approximately five minutes, and the temperature during this process did not exceed $8{ }^{\circ} \mathrm{C}$. The sausage batter was then stuffed into a natural pork casing. After this, the raw sausages were left for approximately for one hour in the room, to allow the proteins to dissolve. The raw sausages were then cooked in a water bath $1.5 \mathrm{~h}$ at $80{ }^{\circ} \mathrm{C}$ (to reach internal temperature of $72{ }^{\circ} \mathrm{C}$ for $10 \mathrm{~min}$ ) and then smoked for one hour at $70{ }^{\circ} \mathrm{C}$ in a smoking chamber. All batches, after cooling down to $5{ }^{\circ} \mathrm{C}$, were then vacuum-packed and stored at $5{ }^{\circ} \mathrm{C}$ for 28 days. Cooking loss was determined during processing. Antioxidant activity, total polyphenol content (TPC), and basic composition chemical composition were measured on the 1st day of storage. The $\mathrm{pH}$, thiobarbituric acid reactive substances (TBARS), CIE L*a*b* color measurement, and microbiological and sensory analysis were assessed on the 1 st, 7 th, 14 th, and 28 th day of storage.

\subsection{Cooking Loss}

The sausages were weighted before and after cooking, after cooling down. The cooking loss was calculated according to the following formula:

Cooking loss $(\%)=[($ weight before cooking - weight after cooking $) /$ weight before cooking $] \times 100$

Cooking loss was calculated for each treatment group in triplicate.

\subsection{Water-Holding Capacity (WHC) of OPP}

The water-holding capacity of OPP was determined according to the method described by Benítez et al. [23] with slight modification. Briefly, $1 \mathrm{~g}$ of OPP was shaken in a laboratory shaker (180 rpm) in $10 \mathrm{~mL}$ of distilled water, at room temperature, for $24 \mathrm{~h}$, in a $15 \mathrm{~mL}$ centrifuge tube. The mixture was then centrifuged $(2500 \times g$ for $30 \mathrm{~min})$. The supernatant was transferred to a graduated $10 \mathrm{~mL}$ cylinder, where the volume was measured. The result was expressed as $\mathrm{mL}$ of $\mathrm{H}_{2} \mathrm{O}$ held by $1 \mathrm{~g}$ of OPP. The analysis was conducted in triplicate.

\subsection{Microbiological Analysis}

The prepared fish sausages (before heat treatment, and after heat treatment in, storage days 0 , $7,14$, and 28$)$ were aseptically sampled (10 g/sample), mixed with $0.1 \%$ peptone $(90 \mathrm{~mL})$ in a sterile plastic bag, and homogenized for $1 \mathrm{~min}$, using an electric stomacher (Stomacher 400 Circulator, Fisher Scientific, spol. s r.o., Pardubice, Czech Republic). Serial 10-fold dilutions were prepared from each 
sample using $1 \mathrm{~mL}$ in $0.1 \%$ peptone $(9 \mathrm{~mL})$. The total viable counts (TVCs) were determined by using the pour plate method according to ISO 4833 [24] and the plates were incubated at $30{ }^{\circ} \mathrm{C}$ for $72 \mathrm{~h}$. Horizontal method was used for enumeration of psychrotrophic bacteria [25], and colonies were counted in a solid medium after incubation at $6.5^{\circ} \mathrm{C}$ for 10 days. The results were expressed as logarithm of colony forming units per gram of sample $\left(\log \mathrm{CFU} . \mathrm{g}^{-1}\right)$.

\subsection{Chemical Analyses}

\subsubsection{Chemicals}

All chemicals, namely quercetin dihydrate (purity $\geq 95 \%$ ), quercetin-3,4'-O-diglucoside (purity $\geq 85 \%$ ), quercetin- $4^{\prime}-O$-glucoside (purity $\geq 95 \%$ ), gallic acid (purity $\geq 99 \%$ ), sodium acetate (purity $\geq 99 \%$ ), acetic acid (purity $\geq 99 \%$ ), sodium acetate (purity $\geq 99 \%$ ), sodium carbonate, ferric chloride, hydrochloric acid ( $\mathrm{HCl} ; 37 \%)$, 2,4,4-tris(2-pyridyl)-1,3,5-triazine (TPTZ, purity $\geq 98 \%$ ), 2,2-diphenyl-1-picrylhydrazyl (DPPH), Trolox (purity $\geq 97 \%$ ), Trolox (purity $\geq 97 \%$ ), Folin-Ciocalteau's phenol reagent, thiobarbituric acid (purity $\geq 98 \%$ ), butylated hydroxytoluene (BHT; purity $\geq 99 \%$ ), 1,1,3,3-tetraethoxypropane (TEP), trichloroacetic acid (TCA; purity $\geq 99 \%$ ), ortho-phosphoric acid (PA; purity $\geq 99 \%$ ), Formic acid (LC/MS grade purity 98-100\%), acetonitrile and methanol LC/MS grade, and ethanol for spectroscopy were purchased from Sigma-Aldrich (Prague, Czech Republic).

\subsubsection{Basic Chemical Composition of Onion Peel}

Water content, ash, crude protein (CP), ether extract (EE), and non-soluble fiber fractions were analyzed in OPP. Moisture was determined by drying the sample, at $105^{\circ} \mathrm{C}$, in an oven, to a constant weight, ash content by combustion at $550{ }^{\circ} \mathrm{C}$, for $16 \mathrm{~h}$ in a muffle furnace to obtain light gray ash [26]. Crude protein was determined by the Kjeldahl method, using Velp Kjeltec system UD159 (Mezos spol. s r.o., Hradec Králové, Czech Republic). The amount of nitrogen was multiplied by a factor of 6.25. Lipid content was determined by using an ANKOM XT10 extractor (Ankom Technology, Macedon, NY, USA) with petroleum ether as a solvent. Neutral detergent fiber (NDF), acid detergent fiber (ADF), and acid detergent lignin (ADL) were analyzed according to the modified method of Van Soest et al. [27], using ANKOM A200 Fiber Analyzer (Ankom Technology, Macedon, NY, USA). Afterward, cellulose, hemicellulose, and nitrogen-free extract content were calculated as follows:

$$
\begin{gathered}
\text { Hemicellulose }=\mathrm{NDF}-\mathrm{ADF} \\
\text { Cellulose }=\mathrm{ADF}-\mathrm{ADL}
\end{gathered}
$$

Nitrogen-free extract $=100-(\%$ of water, ash, crude protein, NDF, and ether extract $)$

All analyses of onion peels were assessed in triplicate.

\subsubsection{Basic Chemical Composition of Fortified Fish Sausages}

The basic chemical composition of sausages (Supplementary Materials Table S1), namely water, fat, protein, collagen, and salt content were measured, using Fourier transformation near infrared spectroscopy (FT-NIR) instrumentation (FT-NIR Master ${ }^{\mathrm{TM}}$ N500; BÜCHI, Flawil, Switzerland), according to the manufacturer's instructions. Approximately $50 \mathrm{~g}$ of sample from each group was homogenized, put into a Petri dish, and analyzed by using the NIR Master ${ }^{\mathrm{TM}}$, which scanned samples over an NIR range of $4000-10,000 \mathrm{~cm}^{-1}$, with a resolution of $4 \mathrm{~cm}^{-1}$. Three independent samples from each group were analyzed.

\subsection{4. $\mathrm{pH}$ Measurement}

The $\mathrm{pH}$ of cooked sausages was measured by using a $\mathrm{pH}$ meter equipped with a spear-type electrode (Spear-type electrode HC 124, Fisher Scientific, spol. s r.o., Pardubice, Czech Republic). 
Approximately $25 \mathrm{~g}$ of homogenized sample was used to directly measure $\mathrm{pH}$. Three independent samples from each group were measured.

\subsubsection{Antioxidant Activity}

Two spectrophotometric methods for measurement of antioxidant activity of samples were selected: DPPH assay, to assess free radical scavenging ability, and FRAP assay, to evaluate reducing ability.

Extraction of Samples for DPPH and FRAP Analyses

Then, $0.2 \mathrm{~g}$ of homogenized sample (either OPP of fish sausages) was extracted in $9.8 \mathrm{~mL}$ of $90 \%$ methanol $(v / v)$, shaken in a laboratory shaker for $10 \mathrm{~min}$, and then centrifuged at $7000 \mathrm{RPM}$, at $5{ }^{\circ} \mathrm{C}$ for $15 \mathrm{~min}$. The collected supernatant was further used for DPPH and FRAP (Ferric Reducing Antioxidant Power) analyses. Two independent samples from each treatment groups were taken, and each sample was extracted twice and analyzed (for DPPH and FRAP) in duplicate ( $n=8$ /group).

\section{$\mathrm{DPPH}$}

Antioxidant activity, using DPPH as a reaction agent, was assessed according to Brand-Williams et al. [28] with modifications. To $4 \mathrm{~mL}$ of DPPH solution in methanol $(27.5 \mu \mathrm{g} / \mathrm{mL})$, $100 \mu \mathrm{L}$ of sample extract (either OPP of fish sausages) was added. The mixture of DPPH solution and sample extract was kept for $2 \mathrm{~h}$, in the dark, at room temperature. After this, the absorbance was measured against a blank at $515 \mathrm{~nm}$. The results are expressed as Trolox equivalents (TE)/g FW (fresh weight).

\section{FRAP}

FRAP was analyzed according to the method described by Dudonne et al. [29], but with slight modification. To prepare FRAP reagent, $100 \mathrm{~mL}$ of acetate buffer $(300 \mathrm{mM}, \mathrm{pH} 3.6)$ was mixed with $10 \mathrm{~mL}$ of TPTZ $(10 \mathrm{mM})$ in $40 \mathrm{mM} \mathrm{HCl}$ and with $10 \mathrm{~mL}$ of $10 \mathrm{mM}$ ferric chloride. Then, a $0.1 \mathrm{~mL}$ of sample extract (either OPP or fish sausages) was added to $4 \mathrm{~mL}$ of FRAP reagent. The reaction mixture was kept for $30 \mathrm{~min}$, at $37^{\circ} \mathrm{C}$. The absorbance was measured against the acetate buffer (blank) at $593 \mathrm{~nm}$. Results are expressed as TE/g FW.

\subsubsection{Total Polyphenol Content}

Firstly, $5 \mathrm{~g}$ of homogenized (either OPP of fish sausages) was extracted in $100 \mathrm{~mL}$ of $80 \%$ ethanol $(v / v)$ under reflux $\left(90^{\circ} \mathrm{C} / 120 \mathrm{~min}\right.$.). A modified method of Lachman et al. [30] was used to determine TPC. An aliquot ( $1 \mathrm{~mL}$ ) of filtrate sample extract (as described above) was transferred into a $50 \mathrm{~mL}$ volumetric flask. After this, deionized water $(10 \mathrm{~mL})$, Folin-Ciocâlteu reagent $(2.5 \mathrm{~mL})$ and $20 \%$ sodium carbonate $(7.5 \mathrm{~mL})$ were added to the sample and properly mixed. Then the flask was filled with deionized water up to the mark. The whole reaction mixture was incubated for $120 \mathrm{~min}$ at room temperature, followed by the absorbance measurement at $765 \mathrm{~nm}$. Two independent samples from each treatment group were taken, and each sample was analyzed in duplicate $(n=4)$. The results are expressed as gallic acid equivalents (GAE)/g FW.

\subsubsection{HPLC-MS/MS Quantification of Main OPP Flavonols}

Extraction and HPLC-MS/MS quantification of main flavonol compounds (quercetin, quercetin$4^{\prime}$-O-glucoside, and quercetin-3,4'-O-diglucoside) presented in OPP were assessed according to the method described by Bedrníček et al. [19]. Briefly, $0.25 \mathrm{~g}$ of OPP was mixed in $5 \mathrm{~mL}$ of methanol and extracted in an ultrasonic bath for $15 \mathrm{~min}$ and occasionally shaken. The extract was centrifuged at $4000 \mathrm{rpm}$ for $15 \mathrm{~min}$ and kept at $-18^{\circ} \mathrm{C}$ until analysis.

Then, $5 \mu \mathrm{L}$ of the supernatant was injected into the HPLC-MS/MS system. The analysis was carried out on the HPLC Dionex UltiMate 3000 system coupled with an Agilent 6420 triple-quad 
mass spectrometer (MS) equipped with an electrospray ionization source. Phenomenex Kinetex C18 column with diameters of $150 \times 2.1 \mathrm{~mm}$, (particle size of $2.6 \mu \mathrm{m}$ ), maintained at $35{ }^{\circ} \mathrm{C}$, was used for the separation. Mobile phases consisted of mobile phase A (5\% acetonitrile and $0.5 \%$ formic acid) and B (100 acetonitrile); the flow rate of mobile phase was $0.2 \mathrm{~mL} / \mathrm{min}$. During the separation, mobile phase B linearly increased from 15\% to $70 \%$ within $20 \mathrm{~min}$, and then decreased back to $15 \%$. The following step was column equilibration for $5 \mathrm{~min}$ prior to the next injection. Separated analytes were then introduced into the MS operating in negative mode with the following settings: $11 \mathrm{~L} / \mathrm{min}$ of drying gas $\left(\mathrm{N}_{2}\right)$, nebulizer pressure of 35 psi, gas temperature $300{ }^{\circ} \mathrm{C}$, capillary voltage $-4 \mathrm{kV}$, and cell acceleration voltage of $7 \mathrm{~V}$. Optimized Fragmentor voltages, collision energy voltages, and transitions were optimized for each compound (Supplementary Materials Table S2). Calibration curve was prepared with 6 concentration levels in the range between 0.1 to $25 \mu \mathrm{L} / \mathrm{mL}$. The OPP was extracted twice, and each extraction was analyzed twice $(n=4)$. The results are expressed as $\mu \mathrm{g} / \mathrm{g}$ of FW.

\subsubsection{TBARS Analysis}

Products of secondary lipid peroxidation (TBARS) were measured according to the method of Miller [31]. Then, $1 \mathrm{~g}$ of homogenized sample (three independent samples from each group) was mixed with $0.2 \mathrm{~mL}$ of BHT $(0.2 \mathrm{mg} / \mathrm{mL}$ in methanol) and $9.1 \mathrm{~mL}$ of mixture of TCA/PA (10\% TCA in 0.2 M PA), using homogenizer T18 basic Ultra-Turrax (IKA, Staufen, Germany), and then filtrated. To $1.5 \mathrm{~mL}$ of filtrate, $1.5 \mathrm{~mL}$ of $0.02 \mathrm{M}$ TBA was added. This mixture was then vortexed and heated at $85{ }^{\circ} \mathrm{C}$ for $35 \mathrm{~min}$. After heating, the mixture was pipetted on a 96-well plate, and absorbance was measured at $550 \mathrm{~nm}$ on a spectrophotometer (Plate Reader AF 2200; Eppendorf AG, Hamburg, Germany). A standard calibration curve was prepared by using TEP, and results were expressed as micrograms of malondialdehyde (MDA) per gram of a sample.

\subsection{Color Measurement}

CIE L*a* $b^{*}$ color measurement was measured, using a ColorEye XTH Spectrophotometer (Gretag Macbeth, New Windsor, NY, USA). Slices were chosen as a representative part of the sausages. Results are expressed in the $L^{*} a^{*} b^{*}$ scale. Results are presented as mean of three independent samples.

\subsection{Sensory Analysis}

The analysis was assessed by 9 trained panelists ( 5 men and 4 women, aged 25-70 years) from the Faculty of Agriculture, University of South Bohemia, in České Budějovice, who are familiar with the sensory evaluation of meat products. The sausages were heated in a water bath at $70{ }^{\circ} \mathrm{C}$ for $10 \mathrm{~min}$ prior to sensory analysis and were served warm. Each panelist received approximately $15 \mathrm{~g}$ of each sample (randomly marked with a three-digit number) on a plate, at the same time. Appearance, odor, taste, texture, and overall acceptability were evaluated on a $100 \mathrm{~mm}$ unstructured abscissa $(100=$ like extremely; $0=$ dislike extremely). The intensity of fishy odor was also assessed on the 28th day of storage ( $100=$ very intensive fishy odor; $0=$ no fishy odor). Sensory analysis was conducted in a room (temperature approximately $22^{\circ} \mathrm{C}$ ) equipped with a table for each panelist and daylight-type bulbs for balanced light. Water and bread were served as a taste neutralizer and were consumed between the judging of samples.

\subsection{Statistical Analysis}

Data were analyzed with the program Statistica CZ 12 (Statsoft CR), using one-way analysis of variance (ANOVA) or two-way ANOVA, using the following model with a fixed effect of percentage of $\mathrm{OPP}$, storage, and interaction OPP $\times$ storage:

$$
\mathrm{Y}_{\mathrm{ijk}}=\mu+\mathrm{OPP}_{\mathrm{i}}+\mathrm{S}_{\mathrm{j}}+(\mathrm{OPP} \times \mathrm{S})_{\mathrm{k}}+\varepsilon_{\mathrm{ijk}}
$$


where $\mathrm{Y}_{\mathrm{ijk}}$ is the dependent variables, i.e., $\mathrm{pH}$, TBARS, CIE L*a* $\mathrm{b}^{*}$, sensory characteristics, and cooking loss; $\mu$ is the mean; $\mathrm{OPP}_{i}$ is the percentage of onion peel powder ( $\mathrm{i}=4 ; 0 \%, 1 \%, 2 \%$, and $3 \%$ of OPP); $S_{j}=$ storage $(j=4 ; 0,7,14$ and 28 days $), \varepsilon_{i j}=$ residual error. Fisher's LSD test was used for group comparisons (post hoc test). Pearson's correlation coefficient was used to estimate the association between percentage of OPP addition and antioxidant activity, and TPC, as well as between CIE L*a*b* color measurement and sensory analysis results.

\section{Results and Discussion}

\subsection{Chemical Composition of OPP}

The basic chemical composition, including total polyphenol content, flavonols, antioxidant activity, and WHC, of OPP is summarized in Table 1 . Water accounts for $12.31 \pm 0.04 \%$ of OPP mass. Thus, the remaining part $(87.69 \%)$ is dry matter, which is mainly represented by structural carbohydrates (fiber), where cellulose is dominant $(27.77 \%)$, followed by hemicelluloses $(2.97 \%)$ and lignin $(1.26 \pm 0.24 \%)$. Our finding is consistent with Choi et al. [14], who also found that cellulose is one of the main structural carbohydrates present in onion peel. However, it is well-known that onion peel contains high amounts (up to $28 \%$ ) of pectin [16,32], predominantly composed of galacturonic acid, galactose, rhamnose, and arabinose, which are considered as a part of the soluble fraction of fiber [33]. Pectin should then be included in the remaining part of dry matter (nitrogen-free extract) after excluding crude protein, ether extract, and ash. The composition of dietary fiber gives the material specific properties that could be beneficial for consumers for health reasons, but also for manufacturers of meat products, because, depending on the composition, fiber has the ability to bind water and fat, and to create gels in meat products [10].

Table 1. Basic chemical composition of onion peel powder (OPP).

\begin{tabular}{cc}
\hline Compound (Unit) & Concentration \\
\hline Proximate chemical composition (\%) & \\
Water & $12.31 \pm 0.04$ \\
Crude protein & $2.41 \pm 0.61$ \\
Ether extract & $0.85 \pm 0.03$ \\
Ash & $8.06 \pm 0.01$ \\
\hline Fiber (\%) & $32.00 \pm 0.11$ \\
NDF & $29.03 \pm 0.03$ \\
ADF & $1.26 \pm 0.24$ \\
ADL (Lignin) & 27.77 \\
Cellulose (=ADF - ADL) & 2.97 \\
Hemicellulose (=NDF - ADF) & 44.37 \\
\hline Nitrogen-free extract (\%) & $4.11 \pm 0.15$ \\
\hline Polyphenols (mg/g FW) & $3.40 \pm 0.08$ \\
Quercetin & $0.63 \pm 0.03$ \\
Quercetin-4' -O-glucoside & $78.60 \pm 1.46$ \\
Quercetin-3,4'-O-diglucoside & \\
Total polyphenol content * & $84.97 \pm 2.61$ \\
\hline Antioxidant activity (mg TE/g) & $91.47 \pm 2.81$ \\
DPPH & $4.20 \pm 0.10$ \\
FRAP & $4.65 \pm 0.06$ \\
\hline Water holding capacity (mL/g) & \\
pH (1\% solution) ${ }^{* *}$ & \\
\hline
\end{tabular}

Results are expressed as mean \pm standard deviation based on fresh weight; $\mathrm{TE}=$ trolox equivalent; NDF $=$ neutral detergent fiber; $\mathrm{ADF}=$ acid detergent fiber; $\mathrm{ADL}=$ acid detergent lignin; DPPH = 2,2-diphenyl-1-picrylhydrazil; $\mathrm{FRAP}=$ ferric reducing antioxidant power; $\mathrm{FW}=$ fresh weight. ${ }^{*}$ Expressed as $\mathrm{mg}$ Galic acid equivalent/g; ${ }^{* *} \mathrm{pH}$ of $1 \%$ solution of dissolved onion peel powder in deionized water. 
Crude protein, ether extract and ash content in OPP is $2.41 \pm 0.61 \%, 0.85 \pm 0.03 \%$, and $8.06 \pm 0.01 \%$ of FW, respectively. Benítez et al. [15] reported similar values of crude protein and ash. On the other hand, Negesse et al. [34] measured much lower values not only for crude protein and ash but even for NDF, ADF, lignin, and ether extract.

Main flavonols in OPP were also determined by LC-MS/MS, together with a spectrophotometric determination of TPC. Content of quercetin, quercetin-4'-O-glucoside, and quercetin-3,4'-O-diglucoside is $4.11 \pm 0.15,3.40 \pm 0.08$, and $0.63 \pm 0.03 \mathrm{mg} / \mathrm{g}$, respectively. Quercetin is the most abundant flavonol in OPP which corresponds to the finding of Prokopov et al. [35], who reported a similar concentration of quercetin which was $3.36 \mathrm{mg} / \mathrm{g}$ FW. Regarding quercetin-4'-O-glucoside, we found a similar concentration as Suh et al. [36], who also determined this compound in onion peel as the second most dominant with a concentration of $1.9 \mathrm{mg} / \mathrm{g}$ FW. Only a small concentration of quercetin-3, $4^{\prime}$-O-diglucoside was found in OPP. It is a foreseeable result because, according to Takahama and Hirota [37], quercetin is mainly presented in onion peel as aglycone due to the presence of glucosidases, which release quercetin from the glycosidic bond. Other authors, however, found a concentration of total flavonols, represented mainly by quercetin and only to a smaller extent quercetin- $4^{\prime}-O$-glucoside, in onion peel in the range between $2.6 \%$ and $6.5 \%$ by weight [38].

The concentration of total polyphenols in OPP is $78.60 \pm 1.46 \mathrm{mg} \mathrm{GAE} / \mathrm{g}$ FW. This value is comparable, but slightly higher, than with Chung et al. [21], who reported a concentration of total polyphenols $69.23 \pm 0.44 \mathrm{mg}$ GAE/g DM.

The presence of flavonols in onion peel is tightly related to high antioxidant activity, using DPPH $(84.97 \pm 2.61 \mathrm{mg}$ TE/g FW) and FRAP method (91.47 $\pm 2.81 \mathrm{mg}$ TE/g FW). According to Ly et al. [39], quercetin is the most responsible compound for the high antioxidant activity of onion peel, but also glycosidic forms of quercetin contribute significantly to the total antioxidant activity. Jeon et al. [40] also reported that onion peel shows superoxide dismutase-like activity. According to Shah et al. [12], onion peel extract can scavenge $\mathrm{O}_{2}^{\bullet-}$ and $\mathrm{HO}^{\bullet}$ radicals. Onion peels are also capable to scavenge free radicals in ORAC (oxygen radical absorbance capacity) antioxidant activity measurement [41].

WHC of dietary fiber is an important technological feature that is important for the incorporation of fiber into a meat product recipe. WHC of OPP was found to be $4.20 \pm 0.10 \mathrm{~mL} / \mathrm{g}$ (Table 1). This value seems to be very low compared to onion fiber concentrates that were analyzed by Benítez et al. [23]. They could absorb much more water $(7.9-10.0 \mathrm{~mL} / \mathrm{g})$ than OPP. Furthermore, Mehta et al. [42] summarize the WHC of a wide range of plant fibers as being in the range from $2.8 \mathrm{~mL} / \mathrm{g}$ for wheat bran to $35.4 \mathrm{~mL} / \mathrm{g}$ for sugar beet fiber. In addition, WHC of a fiber is related to its chemical structure, $\mathrm{pH}$, ionic strength, and particle size. Regarding $\mathrm{pH}, 1 \%$ solution of OPP in deionized water has a value of $4.65 \pm 0.06$, indicating its acidic nature, since pectin is an acidic heteropolysaccharide with galacturonic acid (with partly nonmethylated carboxyl groups), as a main structural component [43].

Nevertheless, it is very hard to compare the content of various compounds in onion peel with other authors, since different authors use different layers of onion peel that are either closer to or further from the surface of the onion, and could differ, for example, in moisture content. According to Benítez et al. [15] and Cheng et al. [44], the chemical composition and compound proportions change from the inner to outer layers of onion. Another reason could be that the composition is affected by many factors, such as type of cultivar, stage of maturation, environmental and agronomic conditions, and storage time [14].

\subsection{Cooking Loss}

In general, weight loss of meat products during heat treatment could be lowered by the addition of plant fiber. According to Ktari et al. [45], cooking method, type of additives, and type and amount of fat affect cooking loss. The influence of the addition of different amounts of OPP on the cooking loss of fish sausages is given in Figure 1. Cooking loss ranged from $10.5 \%$ to $21.7 \%$. The lowest value was found paradoxically in samples with no addition of OPP and highest in the group with 3\% of OPP. 
Thus, the $3 \%$ addition of OPP negatively affected this parameter $(p<0.05)$. Control samples did not differ $(p<0.05)$ from samples with $1 \%$ and $2 \%$ of OPP.

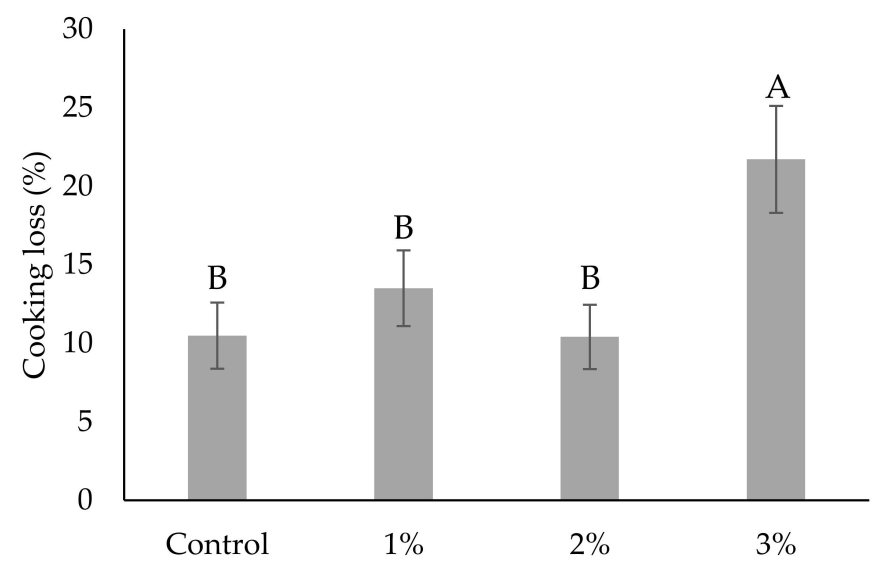

Figure 1. Cooking loss of fish sausages without (control) and with $1 \%, 2 \%$, and $3 \%(w / w)$ of onion peel powder. A,B Bars, representing means $(n=3)$, with different letters differ significantly $(p<0.05)$.

This is very interesting, and the results indicate that a $2 \%$ addition of OPP seems to be a threshold in this particular fish sausage recipe and that, after further addition of OPP, cooking loss increases. There are several explanations that could clarify this phenomenon. It could be explained by the degradation of polysaccharides (especially pectin) in OPP during thermal treatment of fish sausages, which can lead to the lowered water-holding capacity of fiber. Another reason could be that the fiber presented in OPP can absorb water much faster than solubilized proteins of meat, but that is not stable at elevated temperatures, and it releases water during cooking and, hence, increases cooking loss. It indicates that the bond between water and fibre is not as strong as between meat protein matrix and water. According to Feiner [46], WHC is also influenced by $\mathrm{pH}$, because a drop of $\mathrm{pH}$ lowers the amount of water held by meat. Thus, a very low $\mathrm{pH}$ of group with $3 \%$ of OPP (Table 2) could negatively affect its ability to hold water during cooking.

Unlike many experiments that resulted in enhanced WHC and/or cooking loss of meat products enriched with plant dietary fiber $[47,48]$, there have been published several papers that reported that the addition of certain types of plant dietary fiber can negatively influence cooking loss [49-52]. Similar results were obtained by Chung et al. [21], who incorporated $0.3 \%$ and $0.6 \%$ of onion skin powder into Hanwoo Tteok-galbi (traditional Korean beef patties). Cooking loss was the same or slightly higher compared to control samples. Contrary results, on the other hand, were published by Kurt et al. [22], who added $0 \%, 1.5 \%, 3 \%$, and $6 \%$ of onion skin powder into cooked chicken meat patties. Cooking loss decreased as the concentration of onion skin powder increased. However, the later mentioned author used a different recipe of meat product (e.g., with chicken meat), a different thermal treatment $\left(180^{\circ} \mathrm{C} / 15 \mathrm{~min}\right)$, and a different particle size of onion skin powder ( $500 \mu \mathrm{m}$ vs. $\leq 250 \mu \mathrm{m}$ in our study), which could affect results, because, according to Jongaroontaprangsee et al. [53], the particle size of plant dietary fiber powder could alter water absorption.

\subsection{Antioxidant Activity and TPC of Fish Sausages}

Various antioxidants from natural sources have been used to increase the antioxidant activity of meat or meat products, e.g., rosemary extract [9] or red grape pomace [54], in order to improve shelf life, organoleptic properties, or health benefits.

The addition of OPP into fish sausages had a significantly positive effect $(p<0.05)$ on antioxidant activity (DPPH and FRAP) and TPC, compared to the control (Figure 2). As the content of OPP increased, antioxidant activity, and TPC increased, as well. Thus, the lowest values were observed in the control samples and the highest in samples with $3 \%$ of OPP. This is supported by a very strong 
and statistically significant correlation $(p<0.05)$ which was found between the percentage of OPP in fish sausages and DPPH $(r=0.993), \operatorname{FRAP}(r=0.991)$, and TPC $(r=0.993)$ values. It points out that OPP addition contributed significantly to the improvement of antioxidant activity and higher TPC. Despite the fact that no OPP was used in the control group, very low values of antioxidant activity and TPC were found. It could be caused by the presence of other antioxidants occurring in spices used in the recipe. Spices are also source of antioxidant, especially polyphenolic [55]. Increased values of antioxidant activity and TPC in enriched fish sausages indicate that polyphenols in OPP do not decompose completely and at least part of them remains in the finished product. The same trend was already observed in our previous work [20], which focused on onion skin water extracts added into pork patties.

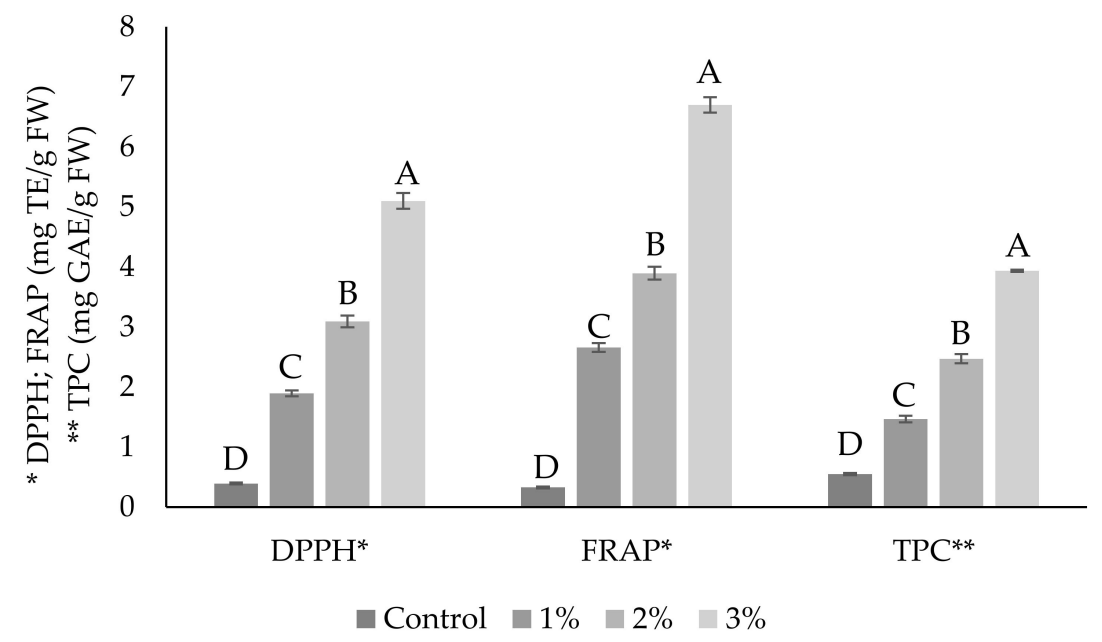

Figure 2. Antioxidant activity (DPPH and FRAP) and total polyphenol content (TPC) of fish sausages without (control) and with $1 \%, 2 \%$, and $3 \%(w / w)$ of onion peel powder. Bars represent means $(n=8$ for DPPH and FRAP; $n=4$ for TPC) \pm standard deviation. A-D Bars within the same analysis with different letters differ significantly $(p<0.05)$.

The results show that OPP is a very rich source of antioxidants, and, even at a very low concentration $(1 \%)$, it can significantly increase the antioxidant activity of certain meat products, especially due to the presence of considerable amounts of quercetin and its derivatives (e.g., glucosides).

\subsection{Changes in Physicochemical, Microbiological, and Sensory Properties of Fish Sausages during Storage}

\subsubsection{Physicochemical Properties}

Maintaining the stability and superior quality of a meat product during a storage period is of the utmost importance [42]. According to Leistner and Gorris [56], $\mathrm{pH}$ is one of the most important factors influencing food preservation and safety. Generally, a reduced $\mathrm{pH}$ value suppresses the growth of bacteria, while strong growth is seen in a $\mathrm{pH}$ range between 6.2 and 6.4 in different types of meat such as beef, chicken, and pork; however, optimal $\mathrm{pH}$ for bacteria growth is seen in a range of 6.1 to 6.7 for fish meat [46]. It was observed that OPP addition significantly $(p<0.05)$ lowered the $\mathrm{pH}$ of fortified fish sausages in a dose-dependent manner, compared to the control samples (Table 2). This reduction of $\mathrm{pH}$ in samples with OPP could be caused by the acidic nature of OPP, as shown in Table 1 ( $\mathrm{pH}$ of $1 \%$ solution of OPP is $4.65 \pm 0.06$ ). As mentioned earlier, onion peels contain high amounts of pectin, primarily composed of galacturonic acid, giving it its acidic nature. The same results were reported by Kurt et al. [22], who incorporated 1.5-6\% of onion skin powder into patties. The higher the concentration of onion skin powder, the lower the $\mathrm{pH}$ was. On the contrary, Chung et al. [21] obtained different results. By increasing the content of onion skin powder, the $\mathrm{pH}$ of Hanwoo Tteok-galbi grew, as well. 
Table 2. Changes in $\mathrm{pH}$, TBARS (thiobarbituric acid reactive substances), and color measurement values $(\mathrm{L}, \mathrm{a}$, and $\mathrm{b}$ ) of fish sausages without (control) and with $1 \%, 2 \%$, and $3 \%(w / w)$ of onion peel powder (OPP) during storage.

\begin{tabular}{|c|c|c|c|c|c|c|c|}
\hline \multirow[b]{2}{*}{ OPP (\%) } & \multicolumn{4}{|c|}{ Storage (Days) } & \multicolumn{3}{|c|}{$p$} \\
\hline & 1 & 7 & 14 & 28 & OPP & Storage & $\begin{array}{c}\text { OPP } \times \\
\text { Storage }\end{array}$ \\
\hline \multicolumn{8}{|l|}{$\mathrm{pH}$} \\
\hline Control & $6.29 \pm 0.02$ & $6.31 \pm 0.01$ & $6.14 \pm 0.04$ & $5.91 \pm 0.00$ & \multirow{4}{*}{$<0.001$} & \multirow{4}{*}{$<0.001$} & \multirow{4}{*}{$<0.001$} \\
\hline 1 & $6.14 \pm 0.02$ & $6.15 \pm 0.01$ & $5.95 \pm 0.01$ & $5.65 \pm 0.02$ & & & \\
\hline 2 & $5.94 \pm 0.01$ & $5.98 \pm 0.02$ & $5.80 \pm 0.05$ & $5.58 \pm 0.02$ & & & \\
\hline 3 & $5.88 \pm 0.00$ & $5.90 \pm 0.01$ & $5.84 \pm 0.04$ & $5.56 \pm 0.03$ & & & \\
\hline \multicolumn{8}{|c|}{ TBARS ( $\mu \mathrm{g}$ MDA/g FW) } \\
\hline Control & $0.44 \pm 0.06$ & $0.75 \pm 0.05$ & $0.73 \pm 0.33$ & $0.71 \pm 0.05$ & \multirow{4}{*}{$<0.001$} & \multirow{4}{*}{0.0464} & \multirow{4}{*}{0.0092} \\
\hline 1 & $0.26 \pm 0.10$ & $0.30 \pm 0.01$ & $0.14 \pm 0.11$ & $0.30 \pm 0.08$ & & & \\
\hline 2 & $0.32 \pm 0.04$ & $0.38 \pm 0.10$ & $0.31 \pm 0.10$ & $0.21 \pm 0.05$ & & & \\
\hline 3 & $0.28 \pm 0.02$ & $0.28 \pm 0.07$ & $0.21 \pm 0.03$ & $0.21 \pm 0.00$ & & & \\
\hline \multicolumn{8}{|c|}{ L-value } \\
\hline Control & $55.34 \pm 0.44$ & $56.84 \pm 1.04$ & $56.39 \pm 0.77$ & $55.82 \pm 0.57$ & \multirow{4}{*}{$<0.001$} & \multirow{4}{*}{0.0002} & \multirow{4}{*}{0.1736} \\
\hline 1 & $48.76 \pm 0.69$ & $51.71 \pm 0.22$ & $50.36 \pm 1.11$ & $49.90 \pm 0.17$ & & & \\
\hline 2 & $48.38 \pm 0.95$ & $48.60 \pm 1.22$ & $48.34 \pm 0.33$ & $48.33 \pm 0.39$ & & & \\
\hline 3 & $44.18 \pm 0.59$ & $46.08 \pm 1.90$ & $46.35 \pm 0.16$ & $46.15 \pm 0.12$ & & & \\
\hline \multicolumn{8}{|c|}{ a-value } \\
\hline Control & $16.91 \pm 0.47$ & $18.09 \pm 0.47$ & $18.80 \pm 0.42$ & $19.90 \pm 0.78$ & \multirow{4}{*}{$<0.001$} & \multirow{4}{*}{0.3339} & \multirow{4}{*}{$<0.001$} \\
\hline 1 & $16.78 \pm 0.25$ & $15.70 \pm 0.25$ & $15.45 \pm 0.43$ & $14.60 \pm 0.50$ & & & \\
\hline 2 & $15.72 \pm 1.30$ & $15.49 \pm 1.30$ & $16.11 \pm 0.75$ & $16.21 \pm 1.69$ & & & \\
\hline 3 & $16.58 \pm 0.42$ & $14.93 \pm 0.42$ & $14.50 \pm 0.31$ & $13.19 \pm 0.20$ & & & \\
\hline \multicolumn{8}{|c|}{ b-value } \\
\hline Control & $31.96 \pm 0.62$ & $32.62 \pm 0.68$ & $32.90 \pm 2.03$ & $33.46 \pm 3.33$ & \multirow{4}{*}{$<0.001$} & \multirow{4}{*}{0.6626} & \multirow{4}{*}{0.4891} \\
\hline 1 & $21.83 \pm 0.41$ & $26.61 \pm 0.65$ & $26.59 \pm 0.61$ & $25.08 \pm 0.58$ & & & \\
\hline 2 & $25.04 \pm 1.84$ & $24.39 \pm 1.68$ & $24.73 \pm 1.07$ & $24.43 \pm 2.41$ & & & \\
\hline 3 & $22.96 \pm 0.41$ & $21.01 \pm 0.90$ & $22.49 \pm 2.10$ & $21.75 \pm 3.30$ & & & \\
\hline
\end{tabular}

Results are expressed as a mean $(n=3) \pm$ standard deviation; FW = fresh weight.

Storage time also significantly $(p<0.05)$ affected $\mathrm{pH}$ of sausages. The $\mathrm{pH}$ of all the sausages continuously decreased during storage with the highest value for the control samples (5.91 \pm 0.00$)$ and the lowest for the samples with $3 \%$ of OPP $(5.56 \pm 0.03)$. This decrease of $\mathrm{pH}$ for all the samples might be due to the presence of spoilage lactic acid bacteria [57] that have a suitable environment for growth in vacuum packed meat products. OPP also contributed to this decrease over time, because a significant $(p<0.05)$ interaction between the percentage of OPP incorporation and storage time was found.

The concentration of secondary lipid oxidation products (TBARS) was also determined (Table 2). The addition of OPP significantly $(p<0.05)$ lowered the concentration of MDA. Even on the first day of storage (after cooking), control samples showed signs of oxidation $(0.44 \pm 0.06 \mu \mathrm{g}$ MDA/g), compared to sausages with OPP, where the oxidation was suppressed $(0.26 \pm 0.10-0.32 \pm 0.04 \mu \mathrm{g} \mathrm{MDA} / \mathrm{g})$. This oxidation is probably a result of the exposure of fats that are prone to oxidation at high temperatures during cooking. Similarly, this phenomenon was described by Kurt et al. [22] and by our previous work [20].

Storage time also significantly $(p<0.05)$ affected TBARS values. During the 28 -day storage period, the concentration of MDA in the control samples grew to values above $0.71 \mu \mathrm{gDA} / \mathrm{g}$, while the samples with OPP remained stably low and did not show any increasing trend. Our results are consistent with Kurt et al. [22], Chung et al. [21], and with Bedrníček et al. [20]. In addition, a strong 
significantly $(p<0.05)$ negative correlation $(r=-0.703)$ was found between $\%$ of OPP and MDA concentration in all days of storage. All of these facts indicate that OPP is a promising additive for meat products that is effective in the suppression of fat oxidation in meat products, owing its strong antioxidant properties to high amounts of quercetin.

The variation in color other than the expected norm may be due to the physical characteristics of meat, the concentration and chemical state of pigments therein, and the presence of non-meat ingredients [10]. Color analysis, using the CIE $\mathrm{L}^{*} \mathrm{a}^{*} \mathrm{~b}^{*}$ system, is summarized in Table 2. OPP addition had a significant effect $(p<0.05)$ on the lightness of fish sausages ( $\mathrm{L}^{*}$ value). The lightness of fish sausages proportionally decreased with an increasing percentage of OPP, except for the first day. The difference between samples with $1 \%$ and $2 \%$ of OPP was small; however, the sample with $3 \%$ of OPP had a very dark color. Lightness was affected also by storage time $(p<0.05)$. $L^{*}$ values of the control samples and samples with $1 \%$ and $2 \%$ of OPP changed with only small alterations, but the samples with $3 \%$ were increasingly lighter over time. Furthermore, $a^{*}$ value (redness) was affected by OPP $(p<0.05)$. Values on the first day slightly differed (between $15.72 \pm 1.30$ and $16.91 \pm 0.47)$, but these differences among treatment groups were more obvious in the later days of storage, where these values were lower with the higher addition of OPP. Again, the samples with $1 \%$ and $2 \%$ of OPP were very similar. It indicates that OPP can cover the typical red color of a meat product. The same trend was also observed in the case of $b^{*}$ value (yellowness), which was also affected by the addition of OPP $(p<0.05)$. This value was also much lower in the samples with OPP. However, this is an unexpected result, to some extent, because our presumption was that the incorporation of OPP would increase the $b^{*}$ value because peels of yellow onion varieties contain quercetin (as mentioned in Section 3.1) which has yellow color [58]. Neither redness nor yellowness was affected by storage time $(p>0.05)$.

\subsubsection{Microbiological Analysis}

The initial microbial loads in separated fish meat were $5.76 \pm 0.02 \log$ CFU.g ${ }^{-1}$ for TVCs and $5.52 \pm 0.02 \log$ CFU.g ${ }^{-1}$ for psychrothrophic bacteria. These relatively high amounts could probably influence the microbial levels in fish sausages before heat treatment, which ranged from $5.29 \pm 0.04 \log$ CFU. ${ }^{-1}$ ( $3 \%$ OPP sample) to $6.03 \pm 0.04 \log$ CFU.g ${ }^{-1}$ ( $1 \%$ OPP sample) for TVCs, and from $5.66 \pm 0.04 \log$ CFU.g ${ }^{-1}$ (control sample) to $7.02 \pm 0.03 \log$ CFU.g ${ }^{-1}$ ( $3 \%$ OPP sample) for psychrothrophic bacteria (Supplementary Materials Table S3). Except for meat, microorganisms could also enter into sausage from other ingredients like spices, as well as from the environment, equipment, and handlers during processing [59]. In our case, the addition of onion peel powder may also have played a role in the initial contamination. On the other hand, similar microbial levels were also found in the control sample. Heat treatment was effective for most of the fish sausage samples examined. Microbial levels on the seventh day of storage ranged from $4.77 \pm 0.07 \mathrm{log}$ CFU.g ${ }^{-1}$ (control sample) to an uncountable amount ( $3 \%$ OPP sample) for TVCs, and from $6.30 \pm 0.10 \mathrm{log}$ CFU.g ${ }^{-1}$ (control sample) to an uncountable amount ( $3 \%$ OPP sample) for psychrothrophic bacteria. These results suggest the development of spore-forming microorganisms. According to Raju et al. [60], fish sausages are considered as an ideal environment for spores and spoilage microorganisms, and heat treatment is not usually effective for all of them. In this context, it should also be taken into account that onion skins are in close contact with the soil, which is known as a rich source of bacterial spores [61]. On the 14th day of storage, the lowest microbial counts were observed in the $2 \%$ OPP sample for both indicator groups, TVC $\left(5.39 \pm 0.03 \log \mathrm{CFU} . \mathrm{g}^{-1}\right)$ and psychrotrophic bacteria $\left(5.71 \pm 0.02 \log \mathrm{CFU} . \mathrm{g}^{-1}\right)$. On the 28th day of storage, all examined samples were found as uncountable.

\subsubsection{Sensory Analysis}

Although a diet enhanced by antioxidants may have considerable health effects, sensory properties should not be neglected. Sensory characteristics, particularly taste and appearance, have a great impact on consumers' preference. The results of the analysis of appearance, odor, taste, texture, and overall acceptability are presented in Figure 3. The intensity of fishy odor on the 28th day of storage is depicted 
in Supplementary Figure S1. The incorporation of OPP significantly $(p<0.05)$ influenced all evaluated sensory parameters.

Day 1

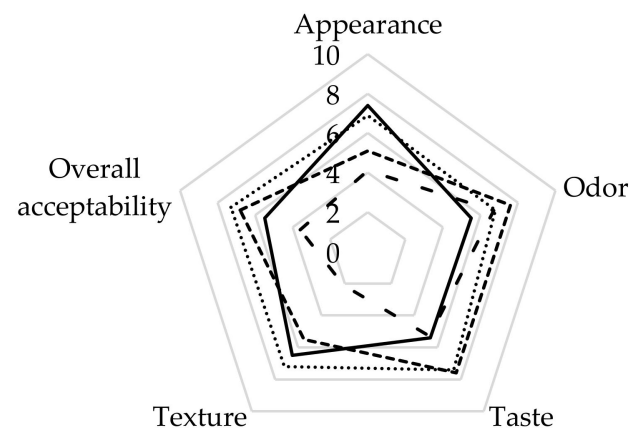

Day 14

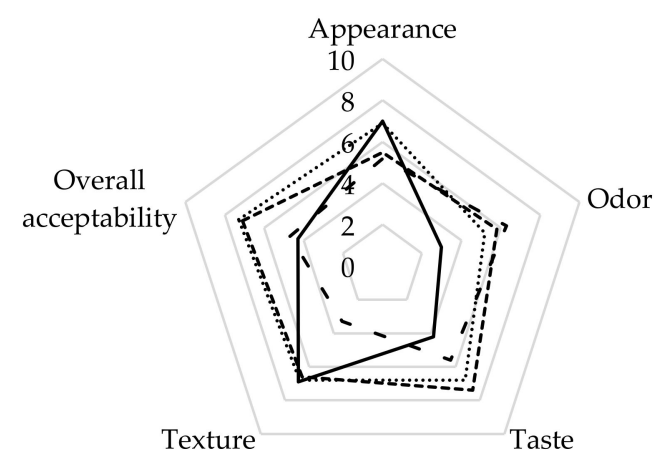

Day 7

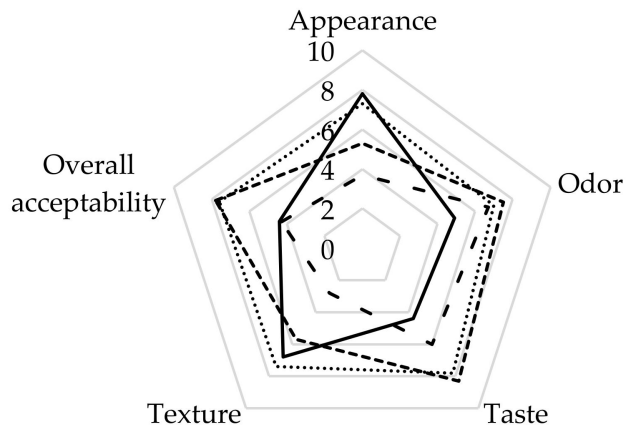

Day 28

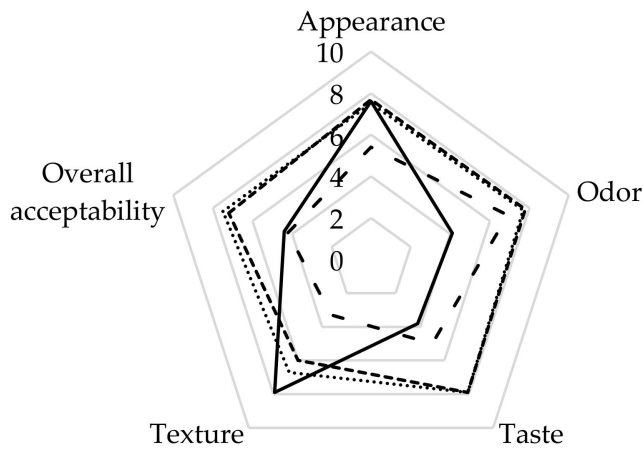

Control $\cdots \cdots \cdot 1 \% \quad--\cdot \cdot 2 \% \quad-\cdot-3 \%$

Figure 3. Changes in sensory characteristics of fish sausages without (control) and with $1 \%, 2 \%$, and $3 \%$ $(w / w)$ of onion peel powder during storage.

It is evident that the addition of more than $1 \%$ of OPP negatively influenced the appearance of fish sausage. The addition of OPP caused darker color, compared to the control group (Table 2), which is not usual for meat products. This is supported by a strong correlation coefficient $(r=0.762, p<0.05)$, suggesting that the lighter the sausage is, the more pleasant appearance it has. Together with this, there was also found a significant correlation between appearance and redness $(r=0.662 ; p<0.05)$. Even though there were slight changes in appearance over time, they were not statistically significant $(p>0.05)$.

The worst score in the case of odor evaluation received the control samples for all days. The addition of OPP positively affected odor pleasantness. Moreover, storage time significantly affected $(p<0.05)$ odor. The pleasantness of odor of control samples continuously decreased over time. This could be related to the presence of fishy odor. It is attributed to compounds including alcohols, aldehydes, ketones, pyrazine, furan and trimethylamine [62]. Furthermore, lipid oxidation is associated with the development of an undesirable fishy odor in fish stored for an extended time [63]. As shown 
in Supplementary Materials Figure S1, after 28 days of storage, the most intensive fishy odor was perceived in the control group. This means that OPP may cover or inhibit the development of fishy odor. This shows an advantage of utilization of OPP in fish sausages, since some consumers do not like fish products because of the fishy smell [6,7]. The intensity of fishy odor strongly correlates $(r=0.999$; $p<0.001$ ) with the concentration of MDA at 28th day of storage.

Taste is also a very important sensory parameter. The assessors regarded samples with $1 \%$ and $2 \%$ of OPP as the tastiest samples over the whole storage period. The control samples and samples with $3 \%$ of OPP received similar values and did not statistically $(p<0.05)$ differ from each other. The taste score of control samples decreased over time; however, these changes were not significant $(p>0.05)$.

Sensory evaluation showed that the most pleasant texture had the control samples and samples with $1 \%$ of OPP. The samples with $2 \%$ and $3 \%$ of OPP were evaluated very negatively. This study confirms with the previous findings of Kurt et al. [22]. The texture of cooked sausages is usually soft; however, OPP contains considerable amounts of non-soluble fiber (Table 1), mainly represented by cellulose. According to Mehta et al. [42], cellulose is responsible for mechanical strength of food. Harder and less preferred texture is, unfortunately, a consequence of the incorporation of OPP. Storage time had no significant effect on texture $(p>0.05)$.

In general, among all the samples, the sensory panel preferred those with $1 \%$ and $2 \%$ of OPP. These samples received the highest score of overall acceptability. This is a satisfactory result, since some consumers do not like the typical fish smell [6], which could still be present in the control samples. On the other hand, $3 \%$ of OPP addition is also below the acceptability threshold. The results of sensory analysis demonstrate that only a small amount (e.g., $1 \%$ ) of OPP is able to enhance the palatability of sausages prepared from mechanically separated fish meat.

\section{Conclusions}

Based on our results, it is evident that OPP is able to extend the shelf life of sausages prepared from separated fish meat. The formation of MDA was suppressed by the addition of OPP, and the overall acceptability was also prolonged during storage. Unfortunately, OPP with a particle size $\leq 250 \mu \mathrm{m}$ is not an appropriate source of dietary fiber that could enhance the technological properties (such as WHC and cooking loss) of fish sausage, which is closely related to the economical aspect of production. However, this problem could be solved by, for example, the reformulation of the meat product recipe, such as the addition of polyphosphates or potato fiber. Overall, the results of this study can be a useful example of the valorization of fish processing by-product together with onion processing by-product that could show a possible way to prevent the loss of valuable nutrients and biologically active substances from the food chain.

Supplementary Materials: The following are available online at http://www.mdpi.com/2076-3921/9/10/974/s1. Figure S1: Intensity of fishy odor of fish sausages without (control) and with $1 \%, 2 \%$, and $3 \%(w / w)$ of onion peel powder evaluated on the 28th day of storage. Table S1: Recipes and chemical composition of fish sausages without (control) and with 1\%, 2\%, and 3\% (w/w) of onion peel powder (OPP). Table S2: Settings of Multiple Reaction Monitoring for quantification of selected flavonoids. Table S3: Total viable counts and counts of psychrotrophic bacteria in fish sausages without (control) and with $1 \%, 2 \%$, and $3 \%(w / w)$ of onion peel powder (OPP).

Author Contributions: Conceptualization, J.B. and F.V.; methodology, J.B. and L.H.; formal analysis, E.S. and J.B.; investigation, I.L., J.B., E.P. and L.H.; resources, J.M. and V.K.; writing-original draft preparation, J.B. and L.H.; writing-review and editing, E.S.; supervision, P.S.; funding acquisition, P.S. and J.K. All authors have read and agreed to the published version of the manuscript.

Funding: This research was funded by (1) Ministry of Agriculture of the Czech Republic, grant number QJ1610324; (2) METROFOOD-CZ, project MEYS, grant number LM2018100; (3) Ministry of Education, Youth and Sports of the Czech Republic, project CENAKVA, grant number (LM2018099), project Cenakva Center Development, grant number CZ.1.05/2.1.00/19.0380, project Biodiversity, grant number CZ.02.1.01/0.0/0.0/16_025/0007370; and (4) University of South Bohemia in České Budějovice, grant numbers GAJU028/2019/Z and GAJU032/2018/T.

Acknowledgments: The authors would like to thank Calvin Schaefer for the proofreading of the manuscript.

Conflicts of Interest: The authors declare no conflict of interest. 


\section{References}

1. Tilami, S.K.; Sampels, S. Nutritional value of fish: Lipids, proteins, vitamins, and minerals. Rev. Fish. Sci. Aquac. 2018, 26, 243-253. [CrossRef]

2. FAO. The State of World Fisheries and Aquaculture 2018-Meeting the Sustainable Development Goals. Available online: http://www.fao.org/3/i9540en/I9540EN.pdf (accessed on 3 September 2020).

3. FAO. The State of World Fisheries and Aquaculture 2020. Available online: https://doi.org/10.4060/ca9229en (accessed on 3 September 2020).

4. Arvanitoyannis, I.S.; Tserkezou, P. Fish waste management. In Seafood Processing: Technology, Quality and Safety, 1st ed.; Boziaris, I.S., Ed.; John Wiley \& Sons Ltd.: Hoboken, NJ, USA, 2014; pp. 263-309.

5. Palmeira, K.R.; Marsico, E.T.; Monteiro, M.L.G.; Lemos, M.; Conte, C.A. Ready-to-eat products elaborated with mechanically separated fish meat from waste processing: Challenges and chemical quality. Cytal. J. Food 2016, 14, 227-238. [CrossRef]

6. Vanhonacker, F.; Pieniak, Z.; Verbeke, W. European consumer perceptions and barriers for fresh, frozen, preserved and ready-meal fish products. Br. Food J. 2013, 115, 508-525. [CrossRef]

7. Leek, S.; Maddock, S.; Foxall, G. Situational determinants of fish consumption. Br. Food J. 2000, 102, 18-39. [CrossRef]

8. Jayathilakan, K.; Sultana, K.; Radhakrishna, K.; Bawa, A.S. Utilization of byproducts and waste materials from meat, poultry and fish processing industries: A review. J. Food Sci. Technol. 2012, 49, 278-293. [CrossRef]

9. Linhartová, Z.; Lunda, R.; Dvořák, P.; Bárta, J.; Bártová, V.; Kadlec, J.; Samková, E.; Bedrníček, J.; Pešek, M.; Laknerová, I.; et al. Influence of rosemary extract (Rosmarinus officinalis) Inolens to extend the shelf life of vacuum-packed rainbow trout (Oncorhynchus mykiss) fillets stored under refrigerated conditions. Aquac. Int. 2019, 27, 833-847. [CrossRef]

10. Das, A.K.; Nanda, P.K.; Madane, P.; Biswas, S.; Das, A.; Zhang, W.G.; Lorenzo, J.M. A comprehensive review on antioxidant dietary fibre enriched meat-based functional foods. Trends Food Sci. Technol. 2020, 99, 323-336. [CrossRef]

11. Munekata, P.E.S.; Gullón, B.; Pateiro, M.; Tomasevic, I.; Domínguez, R.; Lorenzo, J.M. Natural antioxidants from seeds and their application in meat products. Antioxidants 2020, 9, 815. [CrossRef]

12. Shah, M.A.; Bosco, S.J.D.; Mir, S.A. Plant extracts as natural antioxidants in meat and meat products. Meat Sci. 2014, 98, 21-33. [CrossRef]

13. Bravi, E.; Marconi, O.; Sileoni, V.; Rollo, M.R.; Perretti, G. Antioxidant effects of supercritical fluid garlic extracts in canned artichokes. J. Food Sci. Technol. 2016, 53, 3744-3751. [CrossRef]

14. Choi, I.S.; Cho, E.J.; Moon, J.H.; Bae, H.J. Onion skin waste as a valorization resource for the by-products quercetin and biosugar. Food Chem. 2015, 188, 537-542. [CrossRef] [PubMed]

15. Benítez, V.; Mollá, E.; Martin-Cabrejas, M.A.; Aguilera, Y.; Lopéz-Andréu, F.J.; Cools, K.; Terry, L.A.; Esteban, R.M. Characterization of industrial onion wastes (Allium cepa L.): Dietary fibre and bioactive compounds. Plant Food Hum. Nutr. 2011, 66, 48-57. [CrossRef] [PubMed]

16. Jaime, L.; Mollá, E.; Fernández, A.; Martín-Cabrejas, M.A.; López-Andréu, F.J.; Esteban, R.M. Structural carbohydrate differences and potential source of dietary fiber of onion (Allium cepa L.) tissues. J. Agric. Food Chem. 2002, 50, 122-128. [CrossRef] [PubMed]

17. Ren, F.Y.; Nian, Y.Q.; Perussello, C.A. Effect of storage, food processing and novel extraction technologies on onions flavonoid content: A review. Food Res. Int. 2020, 132, 108953. [CrossRef] [PubMed]

18. Piechowiak, T.; Grzelak-Błaszczyk, K.; Bonikowski, R.; Balawejder, M. Optimization of extraction process of antioxidant compounds from yellow onion skin and their use in functional bread production. LWT Food Sci. Technol. 2020, 117, 108614. [CrossRef]

19. Bedrníček, J.; Jirotková, D.; Kadlec, J.; Laknerová, I.; Vrchotová, N.; Tříska, J.; Samková, E.; Smetana, P. Thermal stability and bioavailability of bioactive compounds after baking of bread enriched with different onion by-products. Food Chem. 2020, 319, 126562. [CrossRef]

20. Bedrníček, J.; Laknerová, I.; Linhartová, Z.; Kadlec, J.; Samková, E.; Bárta, J.; Bártová, V.; Mráz, J.; Pešek, M.; Winterová, R.; et al. Onion waste as a rich source of antioxidants for meat products. Czech J. Food Sci. 2019, 37, 268-275. [CrossRef] 
21. Chung, Y.K.; Choi, J.S.; Yu, S.B.; Choi, Y.I. Physicochemical and storage characteristics of Hanwoo Tteokgalbi treated with onion skin powder and blackcurrant powder. Korean J. Food Sci. Anim. Resour. 2018, 38, 737-748. [CrossRef]

22. Kurt, Ş.; Ceylan, H.G.; Akkoç, A. The effects of onion skin powder on the quality of cooked chicken meat patties during refrigerated storage. Acta Aliment. 2019, 48, 423-430. [CrossRef]

23. Benítez, V.; Mollá, E.; Martin-Cabrejas, M.A.; Aguilera, Y.; Esteban, R.M. Physicochemical properties and in vitro antidiabetic potential of fibre concentrates from onion by-products. J. Funct. Foods 2017, 36, $34-42$. [CrossRef]

24. ISO 4833. Microbiology of Food and Animal Feeding Stuffs-Horizontal Method for the Enumeration of MicroorganismsColony-Count Technique at $30^{\circ} \mathrm{C}$; International Organization for Standardization: Geneva, Switzerland, 2003.

25. ISO 6730. Enumeration of Colony-Forming Units of Psychrotrphic Microorganisms-Colony-Count Technique at $6.5^{\circ} \mathrm{C}$; International Organization for Standardization: Geneva, Switzerland, 2005.

26. AOAC 923.03. Official Methods of Analysis of AOAC International; AOAC International: Rockville, ML, USA, 1991.

27. Van Soest, P.J.; Robertson, J.B.; Lewis, B.A. Methods for dietary fiber, neutral detergent fiber, and nonstarch polysaccharides in relation to animal nutrition. J. Dairy Sci. 1991, 74, 3583-3597. [CrossRef]

28. Brand-Williams, W.; Cuvelier, M.E.; Berset, C. Use of a free-radical method to evaluate antioxidant activity. Food Sci. Technol. Lebensm. Wiss. Technol. 1995, 28, 25-30. [CrossRef]

29. Dudonné, S.; Vitrac, X.; Coutière, P.; Woillez, M.; Mérillon, J.M. Comparative study of antioxidant properties and total phenolic content of 30 plant extracts of industrial interest using DPPH, ABTS, FRAP, SOD, and ORAC assays. J. Agric. Food Chem. 2009, 57, 1768-1774. [CrossRef] [PubMed]

30. Lachman, J.; Hosnedl, V.; Pivec, V. Polyphenols in cereals and their positive and negative role in human and animal nutrition. In Cereals for Human Health and Preventive Nutrition; Vaculová, K., Ehrenbergerová, J., Eds.; MZLU: Brno, Czech Republic, 1998; pp. 118-124.

31. Miller, D.D. Lipid peroxidation. In Food Chemistry: A Laboratory Manual; Miller, D.D., Ed.; John Wiley \& Sons Ltd.: New York, NY, USA, 1998; pp. 57-67.

32. Babbar, N.; Baldassarre, S.; Maesen, M.; Prandi, B.; Dejonghe, W.; Sforza, S.; Elst, K. Enzymatic production of pectic oligosaccharides from onion skins. Carbohydr. Polym. 2016, 146, 245-252. [CrossRef] [PubMed]

33. Dhingra, D.; Michael, M.; Rajput, H.; Patil, R.T. Dietary fibre in foods: A review. J. Food Sci. Technol. 2012, 49, 255-266. [CrossRef] [PubMed]

34. Negesse, T.; Makkar, H.P.S.; Becker, K. Nutritive value of some non-conventional feed resources of Ethiopia determined by chemical analyses and an in vitro gas method. Anim. Feed Sci. Technol. 2009, 154, $204-217$. [CrossRef]

35. Prokopov, T.; Slavov, A.; Petkova, N.; Yanakiev, V.; Bozadzhiev, B.; Taneva, D. Study of onion processing waste powder for potential use in food sector. Acta Aliment. 2018, 47, 181-188. [CrossRef]

36. Suh, H.J.; Lee, J.M.; Cho, J.S.; Kim, Y.S.; Chung, S.H. Radical scavenging compounds in onion skin. Food Res. Int. 1999, 32, 659-664. [CrossRef]

37. Takahama, U.; Hirota, S. Deglucosidation of quercetin glucosides to the aglycone and formation of antifungal agents by peroxidase-dependent oxidation of quercetin on browning of onion scales. Plant Cell Physiol. 2000, 41, 1021-1029. [CrossRef]

38. Slimestad, R.; Fossen, T.; Vågen, I.M. Onions: A source of unique dietary flavonoids. J. Agric. Food Chem. 2007, 55, 10067-10080. [CrossRef]

39. Ly, T.N.; Hazama, C.; Shimoyamada, M.; Ando, H.; Kato, K.; Yamauchi, R. Antioxidative compounds from the outer scales of onion. J. Agric. Food Chem. 2005, 53, 8183-8189. [CrossRef] [PubMed]

40. Jeon, S.-Y.; Baek, J.-H.; Jeong, E.-J.; Cha, Y.-J. Potential of onion peel extract as a functional ingredient for functional food. J. Life Sci. 2012, 22, 1207-1213. [CrossRef]

41. Kim, J.; Kim, J.S.; Park, E. Antioxidative and antigenotoxic effects of onion peel extracts in non-cellular and cellular systems. Food Sci. Biotechnol. 2013, 22, 1395-1402. [CrossRef]

42. Mehta, N.; Ahlawat, S.S.; Sharma, D.P.; Dabur, R.S. Novel trends in development of dietary fiber rich meat products-a critical review. J. Food Sci. Technol. 2015, 52, 633-647. [CrossRef] [PubMed]

43. Slavov, A.; Garnier, C.; Crépeau, M.J.; Durand, S.; Thibault, J.F.; Bonnin, E. Gelation of high methoxy pectin in the presence of pectin methylesterases and calcium. Carbohydr. Polym. 2009, 77, 876-884. [CrossRef] 
44. Cheng, A.W.; Chen, X.Y.; Jin, Q.; Wang, W.L.; Shi, J.; Liu, Y.B. Comparison of phenolic content and antioxidant capacity of red and yellow onions. Czech J. Food Sci. 2013, 31, 501-508. [CrossRef]

45. Ktari, N.; Smaoui, S.; Trabelsi, I.; Nasri, M.; Ben Salah, R. Chemical composition, techno-functional and sensory properties and effects of three dietary fibers on the quality characteristics of Tunisian beef sausage. Meat Sci. 2014, 96, 521-525. [CrossRef]

46. Feiner, G. Meat Products Handbook: Practical Science and Technology, 1st ed.; Woodhead Publishing Limited: Cambridge, UK, 2006; p. 672.

47. Ham, Y.K.; Hwang, K.E.; Song, D.H.; Kim, Y.J.; Shin, D.J.; Kim, K.I.; Lee, H.J.; Kim, N.R.; Kim, C.J. Lotus (Nelumbo nucifera) rhizome as an antioxidant dietary fiber in cooked sausage: Effects on physicochemical and sensory characteristics. Korean J. Food Sci. Anim. Resour. 2017, 37, 219-227. [CrossRef]

48. Choi, Y.S.; Kim, H.W.; Hwang, K.E.; Song, D.H.; Jeong, T.J.; Kim, Y.B.; Jeon, K.H.; Kim, C.J. Effects of fat levels and rice bran fiber on the chemical, textural, and sensory properties of frankfurters. Food Sci. Biotechnol. 2015, 24, 489-495. [CrossRef]

49. Henning, S.S.C.; Tshalibe, P.; Hoffman, L.C. Physico-chemical properties of reduced-fat beef species sausage with pork back fat replaced by pineapple dietary fibres and water. LWT Food Sci. Technol. 2016, 74, 92-98. [CrossRef]

50. Kim, D.H.; Shin, D.M.; Seo, H.G.; Han, S.G. Effects of konjac gel with vegetable powders as fat replacers in frankfurter-type sausage. Asian-Australas. J. Anim. 2019, 32, 1195-1204. [CrossRef] [PubMed]

51. Petersson, K.; Godard, O.; Eliasson, A.C.; Tornberg, E. The effects of cereal additives in low-fat sausages and meatballs. Part 2: Rye bran, oat bran and barley fibre. Meat Sci. 2014, 96, 503-508. [CrossRef] [PubMed]

52. Purohit, A.S.; Reed, C.; Mohan, A. Development and evaluation of quail breakfast sausage. LWT Food Sci. Technol. 2016, 69, 447-453. [CrossRef]

53. Jongaroontaprangsee, S.; Tritrong, W.; Chokanaporn, W.; Methacanon, P.; Devahastin, S.; Chiewchan, N. Effects of drying temperature and particle size on hydration properties of dietary fiber powder from lime and cabbage by-products. Int. J. Food Prop. 2007, 10, 887-897. [CrossRef]

54. Sáyago-Ayerdi, S.G.; Brenes, A.; Goñi, I. Effect of grape antioxidant dietary fiber on the lipid oxidation of raw and cooked chicken hamburgers. LWT Food Sci. Technol. 2009, 42, 971-976. [CrossRef]

55. Opara, E.I.; Chohan, M. Culinary herbs and spices: Their bioactive properties, the contribution of polyphenols and the challenges in deducing their true health benefits. Int. J. Mol. Sci. 2014, 15, 19183-19202. [CrossRef]

56. Leistner, L.; Gorris, L.G.M. Food preservation by hurdle technology. Trends Food Sci. Technol. 1995, 6, 41-46. [CrossRef]

57. O'Neill, C.M.; Cruz-Romero, M.C.; Duffy, G.; Kerry, J.P. Shelf life extension of vacuum-packed salt reduced frankfurters and cooked ham through the combined application of high pressure processing and organic acids. Food Packag. Shelf. 2018, 17, 120-128. [CrossRef]

58. Li, Y.; Yao, J.Y.; Han, C.Y.; Yang, J.X.; Chaudhry, M.T.; Wang, S.N.; Liu, H.N.; Yin, Y.L. Quercetin, inflammation and immunity. Nutrients 2016, 8, 167. [CrossRef]

59. Sachindra, N.M.; Sakhare, P.Z.; Yashoda, K.P.; Rao, D.N. Microbial profile of buffalo sausage during processing and storage. Food Control 2005, 16, 31-35. [CrossRef]

60. Raju, C.V.; Shamasundar, B.A.; Udupa, K.S. The use of nisin as a preservative in fish sausage stored at ambient $\left(28+/-2{ }^{\circ} \mathrm{C}\right)$ and refrigerated $\left(6+/-2{ }^{\circ} \mathrm{C}\right)$ temperatures. Int. J. Food Sci. Technol. 2003, 38, 171-185. [CrossRef]

61. Heyndrickx, M. The importance of endospore-forming bacteria originating from soil for contamination of industrial food processing. App. Environ. Soil Sci. 2011, 11, 1687-7667. [CrossRef]

62. Pan, J.F.; Jia, H.; Shang, M.J.; Li, Q.; Xu, C.; Wang, Y.; Wu, H.; Dong, X.P. Effects of deodorization by powdered activated carbon, beta-cyclodextrin and yeast on odor and functional properties of tiger puffer (Takifugu rubripes) skin gelatin. Int. J. Biol. Macromol. 2018, 118, 116-123. [CrossRef] [PubMed]

63. Sae-Leaw, T.; Benjakul, S. Fatty acid composition, lipid oxidation, and fishy odour development in seabass (Lates calcarifer) skin during iced storage. Eur. J. Lipid Sci. Technol. 2014, 116, 885-894. [CrossRef]

(C) 2020 by the authors. Licensee MDPI, Basel, Switzerland. This article is an open access article distributed under the terms and conditions of the Creative Commons Attribution (CC BY) license (http://creativecommons.org/licenses/by/4.0/). 